\title{
MIDDLE CAMBRIAN PELECYPODS FROM THE ANTI-ATLAS, MOROCCO
}

\author{
Gerd GEYER' and Michael STRENG \\ Institut für Paläontologie. Bayerische Julius-Maximilians-Universität \\ Würzburg. Pleicherwall 1. D-97070 Würzburg. Germany. \\ E-mail: gerd.geyer@mail.uni-wuerzburg.de \\ 2 FB-5 Geowissenschaften. Universität Bremen. P. O. Box 330 440. D-28334 \\ Bremen. Germany. E-mail: streng@uni-bremen.de
}

Geyer, G. and Streng, M. 1998. Middle Cambrian pelecypods from the Anti-Atlas, Morocco. [Pelecípodos del Cámbrico Medio del Anti-Atlas, Marruecos.]. Revista Española de Paleontología, n extr. Homenaje al Prof. Gonzalo Vidal, 83-96. ISSN 0213-6937.

\begin{abstract}
A new species of the Early to Middle Cambrian pelecypod genus Pojetaia is reported from the early Middle Cambrian of the Moroccan Anti-Atlas with the new species Pojetaia sarhroensis. Arhouriella opheodontoides n. gen. and sp. is the first report of a Cambrian pelecypod with an amphidetic, slightly twisted and partly internal ligament and appears to represent a second order of pelecypods in the early Middle Cambrian. Preservation, environment and correlation are discussed. Species of Pojetaia are discussed in detail. Jellia is shown to be a junior synonym of Pojeraia. Hence, the species originally described under the names P. runnegari and Jellia ovata by Li and Zhou (1986) need to be renamed. Oryzoconcha He and Pei, 1985 is regarded as an invalid taxon. Other Cambrian pelecypods are reviewed briefly.
\end{abstract}

Key words: Pojetaia sarhroensis n. sp., Arhouriellidae n. fam., Arhouriella opheodontoides n. gen., n. sp., Pelecypoda, morphology, synonymy, phylogeny, preservation, Middle Cambrian, Morocco, China, Australia.

\section{RESUMEN}

Se define Pojetaia sarhroensis, una nueva especie del género de pelecípodo Pojetaia del Cámbrico InferiorCámbrico Medio, procedente del Cámbrico Medio temprano del Anti-Atlas, Marruecos. Se define también Arhouriella opheodontoides n. gen. and sp., que es el primer bivalvo cámbrico descrito con ligamento anfidético ligeramente retorcido y parcialmente interno, por lo que parece representar un segundo orden de pelecípodos en el Cámbrico Medio temprano. Se discute la conservación, el medio de vida y la correlación de este material. Se discuten también, en detalle, las especies de Pojetaia. Jellia se considera un sinónimo más reciente de Pojetaia. Por lo tanto, el material descrito por Li y Zhou (1986) bajo los nombres P. runnegari y Jellia ovata debe ser renombrado. Oryzoconcha $\mathrm{He}$ and Pei, 1985 resulta ser un taxón no válido. Se revisan brevemente otros pelecípodos cámbricos.

Palabras clave: Pojetaia sarhroensis n. sp., Arhouriellidae n. fam., Arhouriella opheodontoides n. gen., n. sp., Pelecypoda, morfología, sinonimia, filogenia, conservación, Cámbrico Medio, Marruecos, China, Australia.

\section{INTRODUCTION}

Pelecypods are rare in Cambrian biota. The specimens described herein are the first Middle Cambrian pelecypods from western Gondwana and the first pelecypods from the present-day continent Africa.

The only other western Gondwanan Cambrian pelecypods were reported from Lower Cambrian rocks of the Görlitz area, eastern Germany (Elicki, 1994). Fossils that were originally interpreted as the earliest known pelecypods were described from the Iberian Chains, northeastern Spain under the name Lamellodonta simplex (Vogel, 1962, 1975). However, these remains turned out to be distorted valves of the obolellid brachiopod 


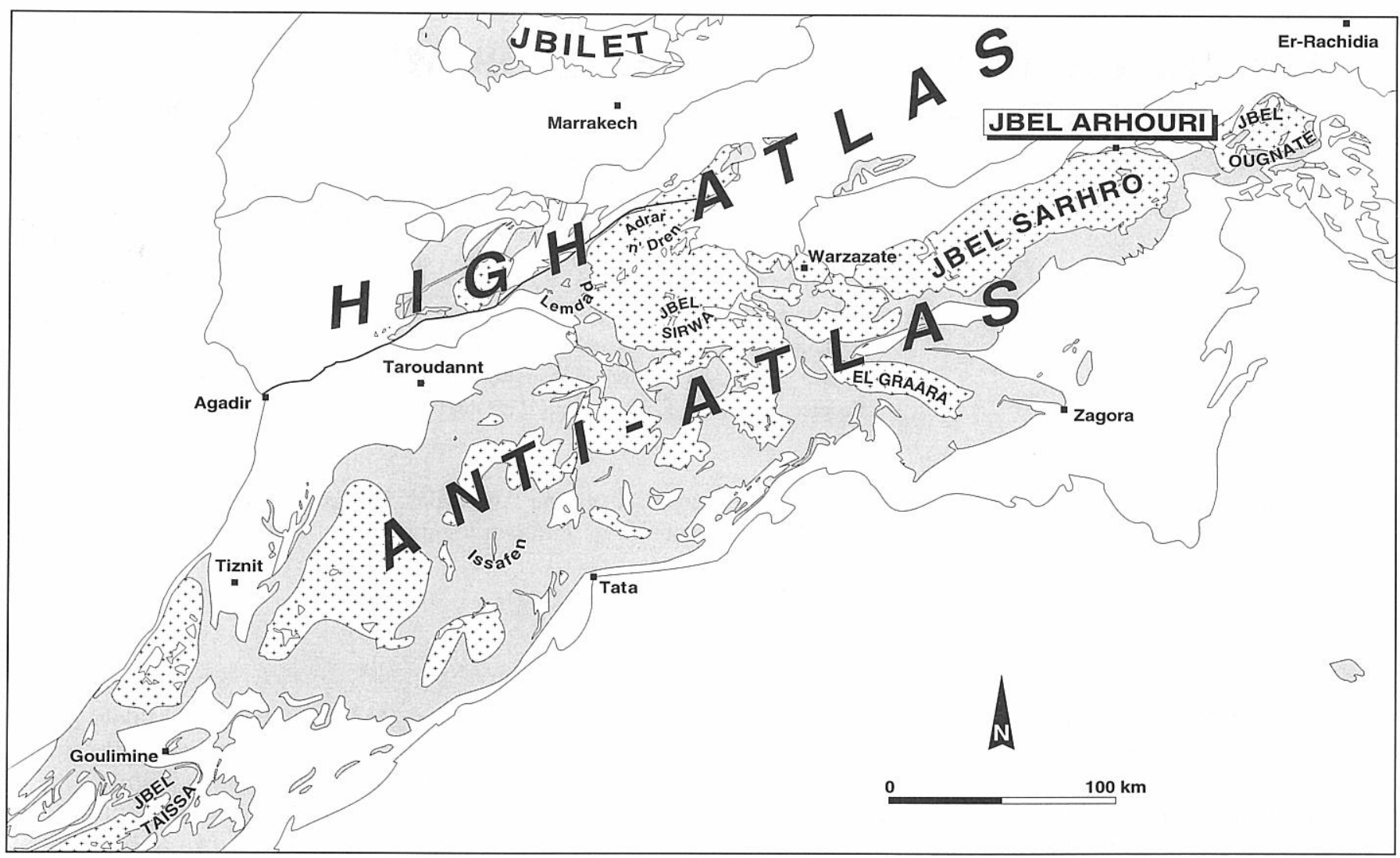

Figure 1. Sketch map of the High Atlas and Anti-Atlas regions, Morocco, illustrating the location of the Jbel Arhouri section and known areas of Neoproterozoic(?)-Cambrian rocks and areas presumed or known to include Neoproterozoic(?)Cambrian rock (stippled), and outcrops of older Neoproterozoic rock and crystalline basement (crosses).

Trematobolus (Pojeta, 1971; Havlíček and Kř́iž, 1978; Geyer and Mergl, 1995).

\section{LOCALITY, AGE, AND ENVIRONMENT}

The specimens all come from sample horizon JAR0.56 of the Jbel Arhouri section, about $5 \mathrm{~km}$ south of Timatraouine on the southern slope of Jbel Arhouri (Lambert coordinates 472/487, on the Dadès map sheet; Fig. 1). The section is probably identical with the locality first discovered by J. Hindermeyer in 1954. Stratigraphic data from this section were used by Hupé (1959) for his Timatraouine section (section 44 in Hupé, 1959). The section was earlier described in detail by Geyer et al. (1995).

The base of the section nonconformably overlies a late Precambrian granitoid complex. The late Precambrian basement in this area was exposed to erosion prior to the lower Middle Cambrian Cephalopyge notabilis Zone. The Middle Cambrian transgression flooded the Jbel Arhouri area during the Cephalopyge notabilis Chron and inundated a granitoid complex creating lithologies that change rapidly laterally (Fig. 2). The basal conglomerates and coarse sandstones are overgrown by laminar and columnar LLH-type stromatolites. Locally, oncoids may rest on the basal laminar algal mats, and columnar stromatolites arise from these oncoidal layers. The space between the columnar stromatolites is filled with reworked debris of shelly fossils, such as trilobites, obolellid and acrotretid brachiopods, echinoderms and numerous small shelly fossils such as helcionellids, pelagiellids and hyoliths. Remarkably, these fossil groups are relatively diverse and contain a number of fossils that are rarely found or even unknown from other localities.

The limestone bed and overlying monotonous finegrained sandstones with intercalated limestone layers represent the Brèche à Micmacca Member of the Jbel Wawrmast Formation, Feijas internes Group (Geyer, 1989, 1990a, 1990c). The stratigraphic concept of this member was derived from a limestone layer exposed near Ourika Wawrmas, north-central Anti-Atlas (compare Geyer and Landing, 1995). Fossil debris, oncoids, and stromatolites represent a shallow marine, high energy nearshore to shoreface environment.

The Pojetaia specimens described herein come from these assemblages. Samples were taken from fossil hash limestones intercalated between stromatolites at the top of the LLH-type stromatolitic limestones and from the overlying centimeters of fossil hash limestones over a distance of several meters in lateral extension (Fig. 3). Trilobites from the assemblages clearly indicate the early Middle Cambrian Cephalopyge notabilis Biozone (Geyer, 1990b). The Cephalopyge Zone is a representative of the Acimetopus/Acidiscus assemblage (Robison et al., 1977; 


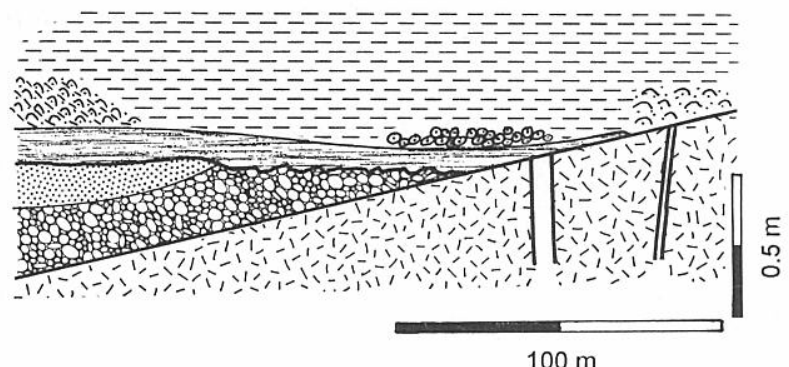

Figure 2. Schematic overview of the sequence boundary at the base of the Jbel Arhouri section. The obliquely truncated granitic basement is pierced by Hercynian aplitic dikes that caused local thermal metamorphism. Conglomerates and local overlying coarse-grained sandstones (small stipples) end at an erosional surface that is capped by stromatolitic-shelly layers (horizontal hachures) with primarily low cyanobacterial mats. Oncoidal and oolitic lenses, as well as columnar LLH- or $\mathrm{SH}-\mathrm{V}$-type stromatolites, overgrow this layer and suggest a second stage of deposition. (After Geyer et al., 1995: fig. 22.)

Geyer 1990b, d) which is commonly regarded as late Early Cambrian in age, and its faunas have been compared with faunal associations of other realms, such as those of the protolenid interval ("Protolenus zone") of Comley, Shropshire, the Acidiscus theristes and Bathydiscus taconicus "subzones" of southeastern Newfoundland (Fletcher, 1972; Landing, 1992), and less clearly with the faunas of the upper Toyonian Stage of Siberia (Geyer, 1990d). Correlation of the Cephalopyge Zone into Laurentia is a matter of uncertainty at present, owing to strong faunal provincialism. Further discussion on the stratigraphy is detailed in Geyer (1993), Geyer and Palmer (1995), and Geyer (1998).

\section{PRESERVATION}

The limestone beds of the Brèche à Micmacca Member are generally limonitic-rich sparry wackestones and packstones so that fossils with primarily calcitic or aragonitic shells are commonly preserved as limonitic internal and external molds, or their shells are replaced by limonitic substances. Accordingly, most specimens of Pojetaia sarhroensis n. sp. from JAR-0.56 are limonitic internal molds, often with parts of the external limonitic coat adhering at the infillings of gaping shell margins. Rarely, steinkerns of Pojetaia sarhroensis may partly be phosphatized. In those cases, only the internal molds are preserved. External coats of the shell most probably attained only minor thicknesses that were unsuitable for preservation during dissolution with formic acid.

Hercynian aplites, which are represented in the Jbel Arhouri section by dikes that pierced the brittle granitoids (Fig. 2), did not intrude the more ductile, Middle Cambrian, fine-grained sandstones. However, they created local metamorphism and partly transformed the

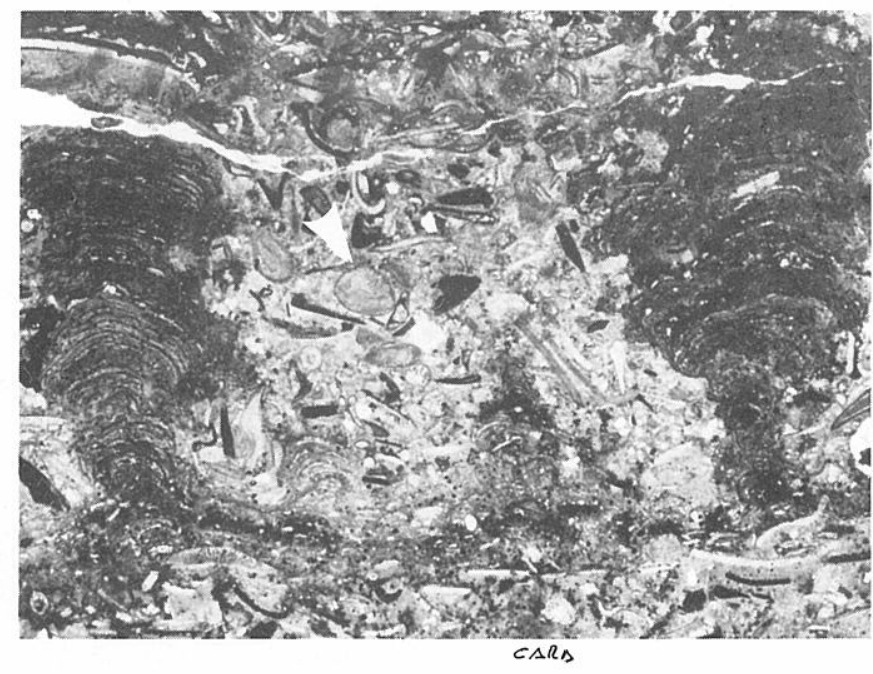

Figure 3. Vertical thin section of bed JAR-0.56 (upper threefourth), showing LLH-type stromatolites which started growth on firm-ground with cyanobacterial mat overlying shell bed. Interspace between stromatolites is now filled with shelly and echinoderm debris and glauconite grains. Arrow points to possible longitudinal section of Pojetaia sarhroensis valve. Width of picture area equals $12 \mathrm{~mm}$.

basal Middle Cambrian conglomerates and limestones. The basal limestones are partly transformed into structureless marbles, and the carbonate was replaced by silica that preserved most of the structures. The bivalves from JAR-0.56 are thus preserved in part as silicified shells.

\section{SYSTEMATIC PALEONTOLOGY}

Specimens examined in this study were obtained by etching of rock samples in dilute formic acid. Limonitic and occasionally phosphatized steinkerns as well as silicified shells were picked from the remaining insoluble residues.

The material is deposited in the collection of the Institut für Paläontologie der Universität Würzburg (PIW), Würzburg (Germany).

\section{CLASS PELECYPODA Goldfuss, 1820}

The record of Cambrian pelecypods includes:

- Fordilla Barrande, 1881, with F. troyensis Barrande, 1881, from the Early Cambrian of the Taconic slice in the New York State (U.S.A.), of Newfoundland, Greenland, Germany, and Bornholm (Denmark), F. sibirica Krasilova, 1977, from the Tommotian of the Siberian Platform, and F. germanica Elicki, 1994, from the Early Cambrian of the Görlitz area (eastern Germany);

- Pojetaia Jell, 1980, with Pojetaia runnegari Jell, 1980 from the Cambrian of South Australia and western New South Wales (additional material described as $P$. runnegari from Anhui Province, China, and from Germany is discussed below), P. ovata Chen and Wang, 1985 from the Early Cambrian of Henan Province, $P$. 


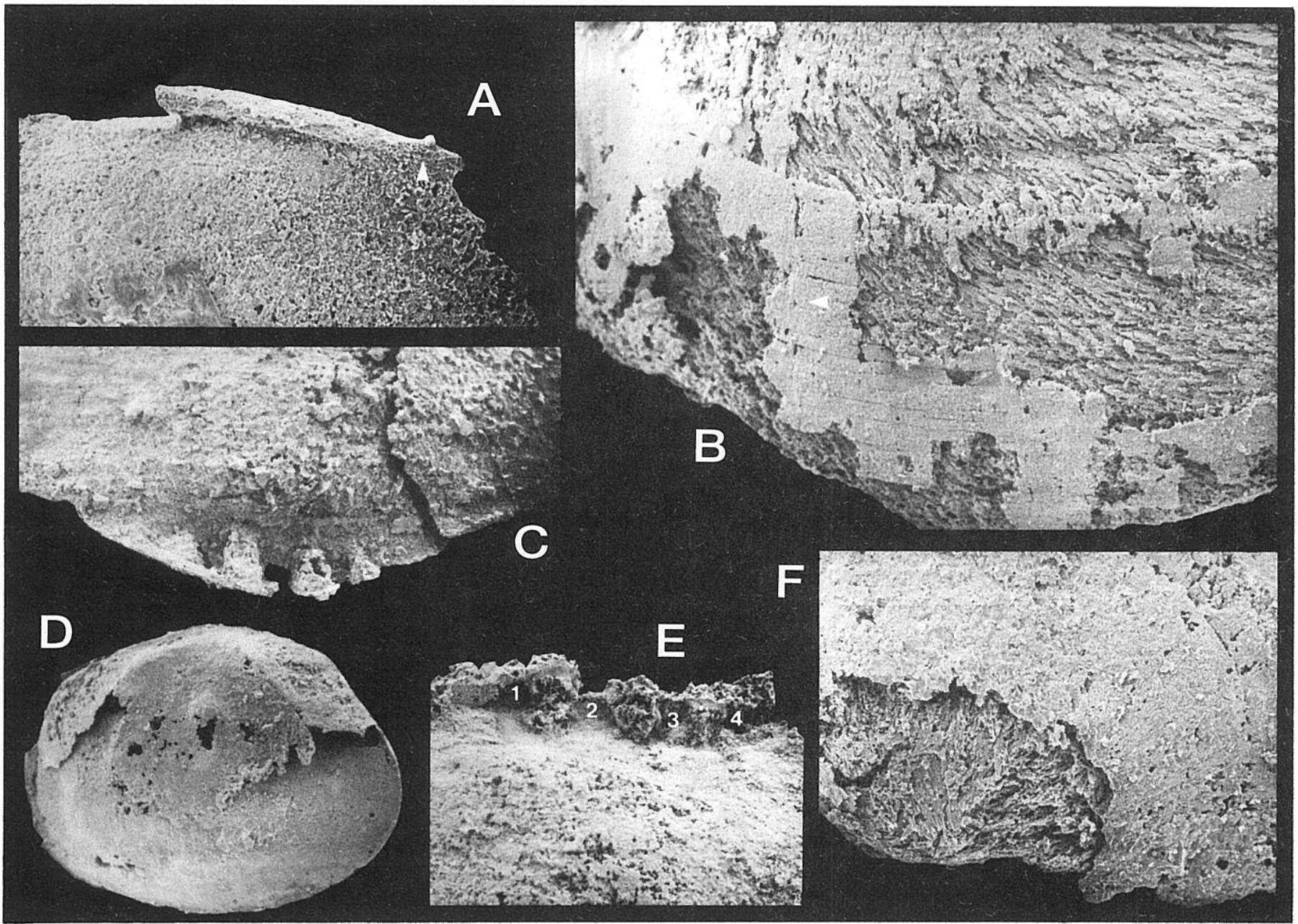

Figure 4. Pojetaia sarhroensis n. sp. All from Jbel Arhouri section, sample horizon JAR-0.56. • A. Paratype, PIW 1997IV24. Detail of internal mold showing posterior hinge area and filling of opisthodetic ligament slot with faint growth lines (arrow). (x150.) - B. Paratype, PIW 1997IV11. Lateral view of limonitized left valve with partially preserved shell structure. (x100.) Note concentric growth lines on external surface and faint radial striae (arrow) that probably sketch aragonitic fibres in the external shell layer of the shell. Corroded areas show crystallite bundles arranged obliquely to the horizontal and radial axes of the shell which indicate irregular prismatic layer. $\bullet$ C. Paratype, PIW 1997IV4. Oblique dorsal view of internal mold with infillings of sockets corresponding to four hinge teeth. (x75.) • D. Paratype, PIW 1997IV21. Left lateral view partly exfoliated specimen showing supposed pallial line/pallial attachment. (x50.) • E. Paratype, PIW 1997IV18. Internal mold, lateral view of hinge with imprints of four hinge teeth. (x75.) - F. Paratype, PIW 1997IV11. Detail of umbonal area with faint concentric growth lines, radial striae and crystallite bundle at corroded umbo. (x150).

elliptica Li and Zhou, 1986 from the Early Cambrian of Anhui Province, both North China Platform, Pojetaia ostseensis Hinz-Schallreuter, 1995 from the Middle Cambrian of Bornholm, and Pojetaia sp. from the Early Cambrian of Bornholm, Denmark (Berg-Madsen, 1987);

Jellia Li and Zhou, 1986, with J. elliptica Li and Zhou, 1986, and J. ovata Li and Zhou, 1986, both from the Early Cambrian of Anhui Province, North China Platform;

Buluniella Yermak, 1986 from the Early Cambrian of the Siberian Platform;

- Tuarangia MacKinnon, 1982, with T. paparua MacKinnon, 1982, from the late Middle Cambrian of New Zealand, T. gravgaerdensis Berg-Madsen, 1987 and T. gravgaerdensis tenuiumbonata Hinz-Schallreuter,
1995, both from the late Middle Cambrian of Bornholm (Denmark), and Tuarangia sp. from an erratic boulder of probable early Late Cambrian age of western Pomerania, Poland (Berg-Madsen, 1987);

- Oryzoconcha He and Pei, 1985, with O. prisca $\mathrm{He}$ and Pei, 1985 from the Early Cambrian of Henan Province, North China Platform;

- Camya Hinz-Schallreuter, 1995 from the late Middle Cambrian of Bornholm, Baltica.

Some of these forms are interpreted as representatives of other fossil groups or as junior synonyms, but it remains especially remarkable and a puzzling fact that no undisputed pelecypods are known from Upper Cambrian strata. For discussion of synonymy under Pojetaia see Discussion under Pojetaia sarhroensis n. sp. below. 

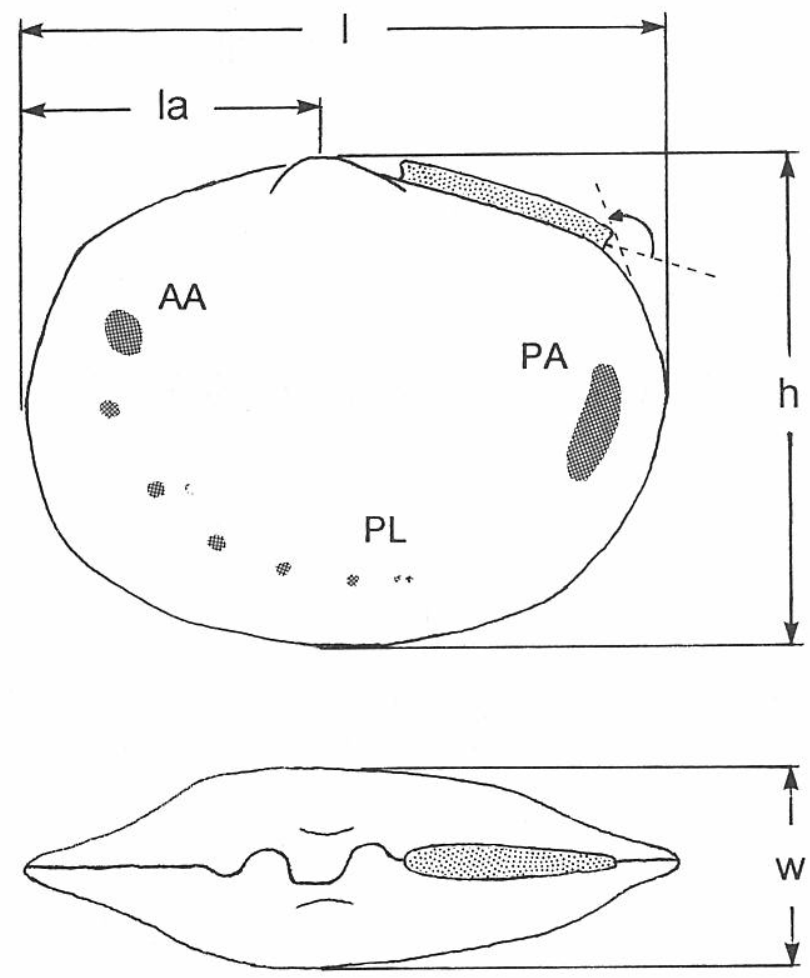

Figure 5. Pojetaia sarhroensis n. sp. Schematic reconstruction of shape, ligament area and muscle scars.

As detailed earlier (Pojeta, 1971; Havlíček \& Kříž, 1978; Geyer and Merg1, 1995), Lamellodonta simplex Vogel, 1962 from early Middle Cambrian strata in the Iberian Chains (that are more-or-less coeval to those with Pojetaia sarhroensis n. sp.) represents a species of the obolellid genus Trematobolus. In addition, Yangtzedonta Yu, 1985 and several other Early Cambrian small shelly fossils have been interpreted as pelecypods. However, preservation and characters are usually inadequate to permit a reliable identification so that their characters should not be used to evaluate early pelecypod phylogeny and evolution. In particular, the interpretation of the following taxa, all from the Early Cambrian of Hubei Province on the Cambrian Yangtze Platform, is refused: Praelamellodonta Zhang, 1980, with P. elegansa [sic] Zhang, 1980, and Praelamellodonta sp.; Xianfengoconcha Zhang, 1980, with X. elliptica Zhang, 1980, and X. rotunda Zhang, 1980; Cycloconchoides Zhang, 1980, with $C$. venustus Zhang, 1980; and Hubeinella Zhang, 1980 , with $H$. formosa Zhang, 1980. All of them are based on slightly or considerably distorted valves of inarticulate brachiopods rather than pelecypods. Accordingly, the Superfamily Praelamellodontacea Zhang, 1980, and the Praelamellodontidae Zhang, 1980, and Cycloconchoididae Zhang, 1980 are invalid as systematic groupings of the Pelecypoda. Shu (1986) described Xianfengoconcha elliptica Zhang, 1980 and X. elongata Shu, 1986, from the Early Cambrian Niutitang Formation of Guizhou (China). The figured specimen assigned to $X$. elliptica has blade-like structures such as the material described from Hubei. These structures are interpreted as teeth. However, it remains doubtful whether the Guizhou material is congeneric or even conspecific with $X$. elliptica as described by Zhang (1980). Both X. elliptica (known from a single specimen) and $X$. elongata (known from three slightly to considerably distorted specimens) have a pelecypod-type habit, but are inadequately preserved for systematic determination.

Tuarangia MacKinnon, 1982 has been interpreted as a bivalved "monoplacophoran" rather than a pelecypod (Runnegar, 1983; Runnegar and Pojeta, 1985). Although Tuarangia is a striking analogy of the "quasirostroconch" Pseudomyona Runnegar, 1983, morphological details that support this interpretation remain equivocal, and more material of further related taxa is needed to give evidence for either interpretation.

Camya Hinz-Schallreuter, 1995 is known only from the type material, two strongly inequilateral left and possibly juvenile valves, that do not show any clear dentition.

The species of Fordilla range from the early late Early Cambrian to the late late Early Cambrian (probable equivalents of the Siberian Atdabanian and Botoman); Pojetaia was previously known from the upper Tommotian to the earliest Middle Cambrian in Australia (probable equivalents of the Siberian upper Toyonian) and is now also known (this paper) from probable equivalents of the Siberian upper Toyonian in Morocco.

SUBCLASS PALAEOTAXODONTA Korobkov, 1954

\section{ORDER NUCULOIDA Dall, 1889}

\section{Family Praenuculidae McAlester, 1969}

The family Praenuculidae includes Early Cambrian through Devonian nuculoids with a simple, external ligament. Fordilla and Pojetaia resemble juvenile individuals of more advanced praenuculids so that they can be accomodated in this family although their characters are few and relatively insignificant.

\section{Pojetaia Jell, 1980}

Type species: Pojetaia runnegari Jell, 1980, p. 235 (by original designation).

\section{Discussion}

Despite the general paucity of Cambrian pelecypods, Pojetaia is a widespread genus, now known from Australia, China, Morocco, Germany, and Denmark. Although the characters are limited in number, they permit identification of a number of species with limited geographic ranges. Examination of published species suggests modification of the nomenclature of several forms.

Pojetaia ovata Chen and Wang, 1985 was described from the Early Cambrian of Henan, on the North China 

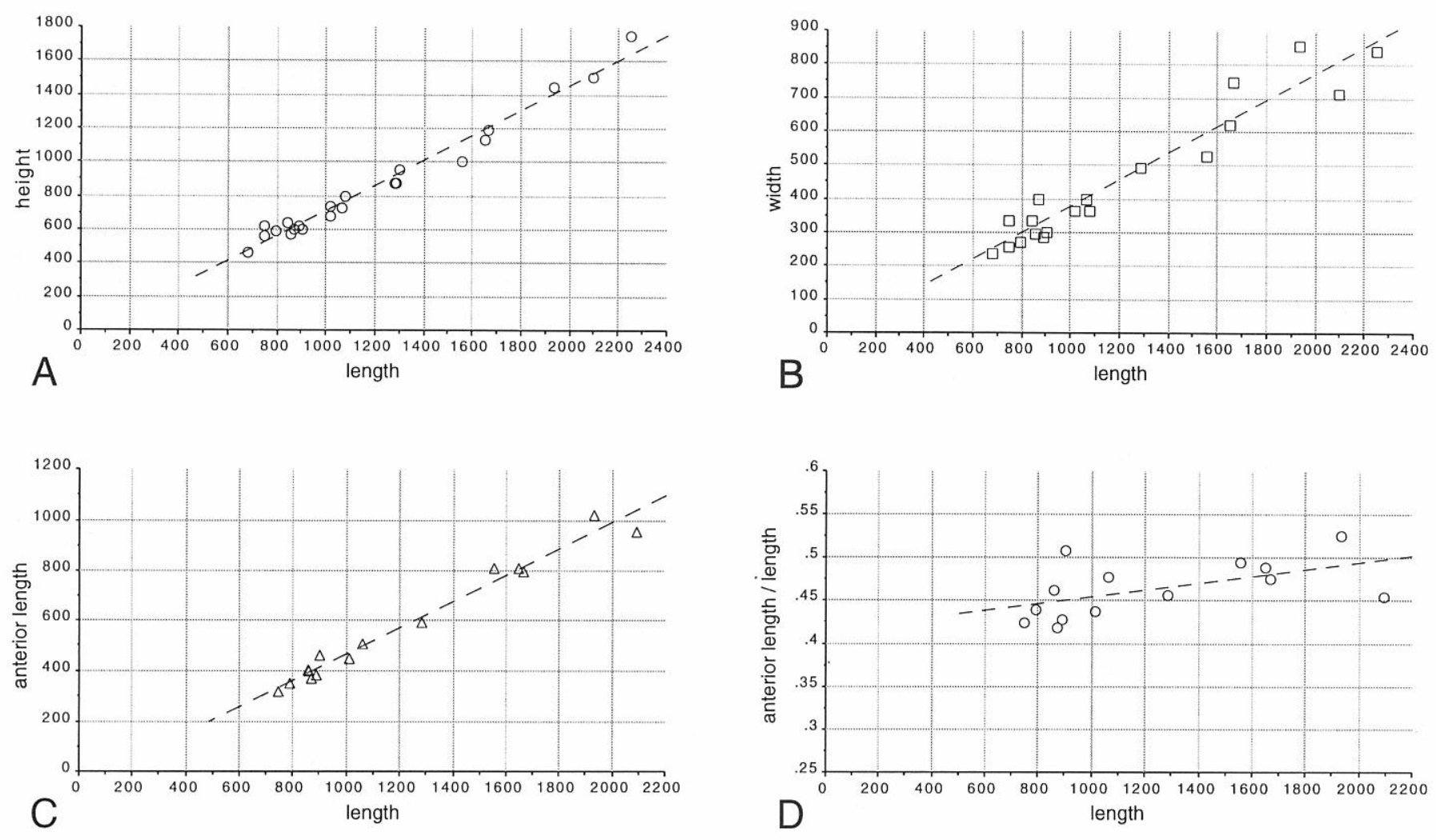

Figure 6. Relations of dimensions in Pojetaia sarhroensis n. sp. $\bullet$ A. Total length vs. height. $\bullet$ B. Length vs. width. $\bullet$ C. Total length vs. anterior length. $\bullet$ D. Total length vs. ratio anterior length/total length. (All values in $\mu \mathrm{m}$.) See figure 5 for location of measurements. Explanations in the text.

Platform. Specimens from the same and nearby localities were described as Pojetaia runnegari by He and Pei, 1985, but represent the same distinct species.

$\mathrm{Li}$ and Zhou (1986) described two genera and four species of pelecypods from the Lower Cambrian Yutaishan Formation of Anhui on the North China Platform, under the names Pojetaia runnegari Jell, 1980, P. elliptica Li and Zhou, 1986, Jellia elliptica Li and Zhou, 1986, and J. ovata Li and Zhou, 1986. The authors refused the interpretation of a common transposition of the teeth, and their new genus Jellia Li and Zhou, 1986 is based on forms with a "main tooth" on the right valve, whereas the concept of Pojetaia is reduced to only include forms with the "main tooth" on the left valve. The two species found for Pojetaia and Jellia are thus morphological counterparts placed into two different genera. However, we interprete these pairs of species as representatives of a single species each with frequently transposed hinge. This interpretation follows that for Fordilla and Pojetaia by Krasilova (1977), Jell (1980), and Runnegar and Bentley (1983). Transposition was apparently a common feature in the Cambrian pelecypods, but is a character that is occasionally observed in post-Cambrian and even recent pelecypods. Thus, Jellia elliptica is a synonym of Pojetaia elliptica, and Jellia ovata is a synonym of Pojetaia runnegari of Li and Zhou (1986). Both species are distinguished by 1) the shape of the valves which is more subelliptical in $P$. elliptica and more oval in their P. runnegari, and by 2) the auricle which is better developed in their $P$. runnegari and thus creates a smaller angle in lateral view (130-135 in their Chinese $P$. runnegari in contrast to $120-130^{\circ}$ in P. elliptica).

Pojetaia runnegari of Li and Zhou (1986) differs from the type material of $P$. runnegari in having a larger posterodorsal angle of the auricle and less projecting umbones on internal molds; it represents a different species. For this species, the name Jellia ovata $\mathrm{Li}$ and Zhou, 1986, would be available. However, P. ovata (Li and Zhou, 1986) is a junior homonym of $P$. ovata Chen and Wang, 1985. Therefore a new name needs to be chosen.

Fordilla germanica Elicki, 1994 differs from $F$. troyensis Barrande, 1881 and F. sibirica Krasilova, 1977 in having an elongate rather than oval lateral outline, subcentral umbones, and a small posterodorsal auricle. These characters suggest that the species is better placed in Pojetaia.

Oryzoconcha $\mathrm{He}$ and Pei, 1985 (type species, $O$. prisca $\mathrm{He}$ and Pei, 1985), from the Early Cambrian of Henan, North China Platform, is based on imperfectly preserved material and on specimens with characters of Pojetaia and is thus a junior synonym of Pojetaia as suggested earlier by Runnegar (in Berg-Madsen, 1987).

\section{Pojetaia sarhroensis n. sp.} Figs. 4-6; Pl. I

Holotype: PIW 1997IV25 (Pl. I, fig. 12). Paratypes: 49 internal molds with or without partial limonitic coats, 


\begin{tabular}{|c|c|c|c|c|c|c|}
\hline SPECIES & REFERENCE & OCCURENCE & SHAPE & $\begin{array}{c}\text { BEAKS } \\
\text { ON STEINKERN }\end{array}$ & $\begin{array}{l}\text { AURICLE } \\
\text { ANGLE }\end{array}$ & DENTITION \\
\hline P. runnegari & Jell, 1980 & southern Australia & oval & prominent & $110-120^{\circ}$ & 2 hinge teeth \\
\hline P. ovata & Chen \& Wang, 1985 & $\begin{array}{l}\text { Henan Province, } \\
\text { North China Platform }\end{array}$ & oval & short & $110-120^{\circ}$ & $\begin{array}{l}2-3 \text { hinge teeth, } \\
\text { middle tooth largest }\end{array}$ \\
\hline P. elliptica & Li \& Zhou, 1986 & $\begin{array}{l}\text { Anhui Province, } \\
\text { North China Platform }\end{array}$ & elliptical & short & $120-130^{\circ}$ & $\begin{array}{l}\text { 2-3 hinge teeth, } \\
\text { middle tooth largest }\end{array}$ \\
\hline "J." elliptica & Li \& Zhou, 1986 & $\begin{array}{l}\text { Anhui Province, } \\
\text { North China Platform }\end{array}$ & oval & short & $130-135^{\circ}$ & $\begin{array}{l}2(-3) \text { hinge teeth, } \\
\text { middle tooth largest }\end{array}$ \\
\hline P. germanica & Elicki, 1994 & $\begin{array}{c}\text { Germany, } \\
\text { western Gondwana }\end{array}$ & elliptical & short & $120-130^{\circ}$ & unknown \\
\hline P. sarhroensis & this study & $\begin{array}{c}\text { Morocco, } \\
\text { western Gondwana }\end{array}$ & oval & short & $130-135^{\circ}$ & $\begin{array}{l}2-3(-4) \text { hinge teeth, } \\
\text { size tends to } \\
\text { decrease anteriorly }\end{array}$ \\
\hline P. ostseensis & Hinz-Schallreuter, 1995 & $\begin{array}{c}\text { Bornholm, } \\
\text { Baltica }\end{array}$ & elliptical & short & ca. $135^{\circ}$ & 3 hinge teeth \\
\hline
\end{tabular}

Table I. Comparison of distinctive characters in the species of Pojetaia. Explanation in the text.

deposited under PIW 1996X32.1, PIW 1997IV1 through PIW 1997IV7, PIW 1997IV9 through PIW 1997IV19, PIW 1997IV21 through PIW 1997IV29 and PIW 1997IV30a-u. Additional material tentatively assigned to $P$. sarhroensis under PIW 1997IV31a-c.

Locus typicus: Jbel Arhouri section, east-central Anti-Atlas.

Stratum typicum: Sample horizon JAR-0.56, Jbel Warwmast Formation, Brèche à Micmacca Member; Cephalopyge notabilis Zone, early Middle Cambrian.

Derivatio nominis: Named after the Jbel Sarhro area, eastcentral Anti-Atlas, Morocco, in which the type locality is located.

Diagnosis: Posterior auricle faintly marked and narrow. Dentition of (usually) sinistral valve of adult individuals with three teeth, anterior tooth minute.

\section{Description}

Shell equivalved, roughly equilateral. Valves of adult specimens veneriform and oval, juvenile valves elongate. Umbones prosogyrate, beaks near midlength, poorly projecting in internal molds. Posterior auricle faintly marked, includes posterior angle of approximately 130 to $135^{\circ}$ in lateral view of adult valves.

Exterior of valves usually smooth or with faint growth lines, rarely with shallow, broad concentric ribs. Anterior sector sometimes defined by one ore two shallow radial ribs. Very fine radial lines seen in PIW 1997IV11 (Fig. 4B, F) are due to corrosion and possibly mark junction of crystallite bundles with the external surface of the outer shell layer.

Interior of valves smooth, except for multiple-paired pedal muscle scars arranged in a position similar to a supposed pallial line/pallial attachment. Number of pallial muscle tracks vacillates from five to probably nine, with broader and less discrete imprints in the anterior part, and form a non-sinuate trail (Pl. I, figs. 5, 6, 8, 9; Fig. 4D).
Probable anterior adductor muscle scar relatively small, located at anterior end of pallial muscle tracks. Anterior pedal retractor muscle insertion is faintly indicated relatively close to the anterior end of the hinge in one of the specimens.

Dorsal margins of valves strengthened. Ligament opisthodetic, with almost half shell length, lenticular in dorsal view. Ligament areas elongate, straight, occasionally with growth lines (Fig. 4A, B).

Dentition consists of generally two to three peg-like teeth and corresponding sockets, occasionally with four sockets or teeth (Fig. 4C, E). A silicified left valve has a hinge plate that carries three stout and broad-based teeth which decrease in size posteriorly (Pl. I, figs. 1-3). Dentition sometimes transposed (compare Pl. I, figs. 10 and 12).

\section{Ontogeny and autoecology}

The studied material includes isolated valves and steinkerns that range from 680 to $2,250 \mu \mathrm{m}$ in length and thus represent an ontogenetic series from immature through most probably gerontic individuals. Although the 50 sampled individuals are clearly less than those of Pojetaia runnegari studied by Runnegar and Bentley (1983), the size range clearly exceeds that reported from Pojetaia runnegari ( 0.7 to $1.6 \mathrm{~mm}$; Runnegar and Bentley, 1983: 82). This indicates that the specimens may, at least partly, represent populations composed of individuals of different ages that were killed by rapid burial.

Small and hence juvenile valves are usually subelliptical in shape and reach a ratio of height to length of more than 0.8 (0.83 in PIW 1997IV30a), whereas large individuals usually have a ratio of height to length of 0.66 to 0.68 . Accordingly, the posterodorsal auricle is much longer in those specimens and the auricle angle includes occasionally more than $135^{\circ}$.

In accordance with the increase in size, small individuals have a dentition consisting of two teeth, whereas large specimens have three or, rarely, four teeth. 
Most of the examined specimens are preserved bivalved. As they were dissolved from shell hash layers with disarticulated or even fragmented sclerites of trilobites, hyoliths, chancelloriids, echinoderms and other fossil groups, this suggests that the individuals lived infaunally and were normally preserved in their original habitat.

\section{Size and growth}

Lengths of the internal molds range from 680 to 2,250 $\mu \mathrm{m}$, heights from 460 to $1750 \mu \mathrm{m}$, and width of the internal molds from 240 to about $850 \mu \mathrm{m}$. The values are roughly normally distributed, but the number of the measured specimens $(\mathrm{N}=22)$ is too small to permit statistically significant analyses.

The average ratio of anterior length to total length increases with growing overall length of the valves. This indicates that the apex moves to a progressively central position during life-time.

Regression curves of width to length and height to length (Fig. 6) indicate that allometric growth is insignificant for the major axes.

\section{Shell structure}

One specimen of the examined material is preserved with a partly limonitized shell that allows reconstruction of details of the shell. This specimen shows an external surface with faint concentric growth lines which were reinforced during diagenesis and weathering processes and fine radial striae which we interprete as to depict the radial arrangement of primarily aragonitic fibres. Corroded areas on the valves permit the view of the middle and inner shell layers that now consist of crystallite bundles arranged obliquely to the horizontal and radial axes of the shell (Fig. 4B, F). They permit identification of an irregular prismatic layer. This structure of the inner shell layer is similar to, although not identical with, the aragonitic, columnar prismatic shell structure described from Pojetaia runnegari by Runnegar and Bentley (1983). Polygons on the inner surface as noted from P. runnegari (Runnegar and Bentley, 1983: fig. 4) were not observed in $P$. sarhroensis.

\section{Comparison}

The differences between the species of Pojetaia are remarkably small, but careful investigation of the material indicates that these minor differences are sufficient to characterize distinct species. The paucity of characters and the occurrence in different faunal provinces as well as a general parallelism in mollusc morphotypes between western and eastern Gondwana around the Lower-Middle Cambrian transition corroborate this concept of discrete species.

Pojetaia sarhroensis n. sp. equals $P$. runnegari Jell, 1980 , in most respects. Differences exist in a smaller and less well defined posterior auricle, in the apparently larger posterior hinge tooth, and in the barely projecting umbones of internal molds in $P$. sarhroensis. The posterodorsal tip of the auricle in $P$. runnegari includes an angle of $110-120^{\circ}$.

Pojetaia ovata Chen and Wang, 1985 differs from $P$. sarhroensis in having a clearly larger, well defined posterior auricle, very similar to that in P. runnegari. The posterodorsal tip of this auricle includes an angle of $110-120^{\circ}$. However, unlike $P$. runnegari it has two to three hinge-teeth and corresponding sockets and a less clearly projecting umbo in internal molds, like $P$. sarhroensis.

Pojetaia elliptica Li and Zhou, 1986 (synonym: Jellia elliptica Li and Zhou, 1986) has a similarly faintly developed auricle (and, thus, a similarly large auricle angle of up to about $135^{\circ}$ ), but differs in the more subelliptical shape of the valves.

As mentioned above, Fordilla germanica Elicki, 1994 from the Early Cambrian of eastern Germany has an elongate rather than oval lateral outline, subcentral umbones, and a small posterodorsal auricle and is hence tentatively placed under the genus Pojetaia. Pojetaia

Plate I

Pojetaia sarhroensis $\mathrm{n}$. sp. All from Jbel Arhouri section, sample horizon JAR-0.56.

1-3 Paratype, PIW 1996X32.1, silicified left valve. 1. Internal view. $(x 40.) \cdot 2$. Detail, oblique dorsal view showing dentition consisting of three teeth that decrease in size anteriorly. $(x 75.) \cdot 3$. Oblique anterior view of hinge region with dentition and imperfectly preserved posterior ligament area. (x80.)

4 Paratype, PIW 1997IV1. Dorsal view of internal mold showing pattern of hinge teeth. (x50.)

5 Paratype, PIW 1997IV5. Right lateral view of partly exfoliated specimen, showing muscle tracks along pallial line. (x50.)

6 Paratype, PIW 1997IV2. Right lateral view of largely exfoliated specimen, showing pallial line and imperfectly preserved anterior adductor muscle scar. (x50.)

7 Paratype, PIW 1997IV7. Lateral view of internal mold of hinge region showing peg-like infillings of sockets. (x75.)

8 Paratype, PIW 1997IV29. Lateral view of internal mold of imperfectly preserved small individual with rests of pallial muscle tracks. (x60.)

9 Paratype, PIW 1997IV3. Right lateral view of partly coated internal mold with series of pallial muscle tracks. (x75.)

10 Paratype, PIW 1997IV24. Dorsal view of internal mold, showing filled opisthodetic ligament slot and pattern of hinge teeth. (x75.) Arrow points to hinge tooth corresponding to transposed dentition in Fig. 12.

11 Paratype, PIW 1997IV26. Dorsal view of partly coated internal mold, showing pattern of hinge teeth. (x75.)

12 Holotype, PIW 1997IV25. Dorsal view of partly coated internal mold, showing pattern of hinge teeth and filled ligament slot. (x75.) Note transposition of hinge teeth in comparison to PIW 1997IV24 in Fig. 10. 
Plate I

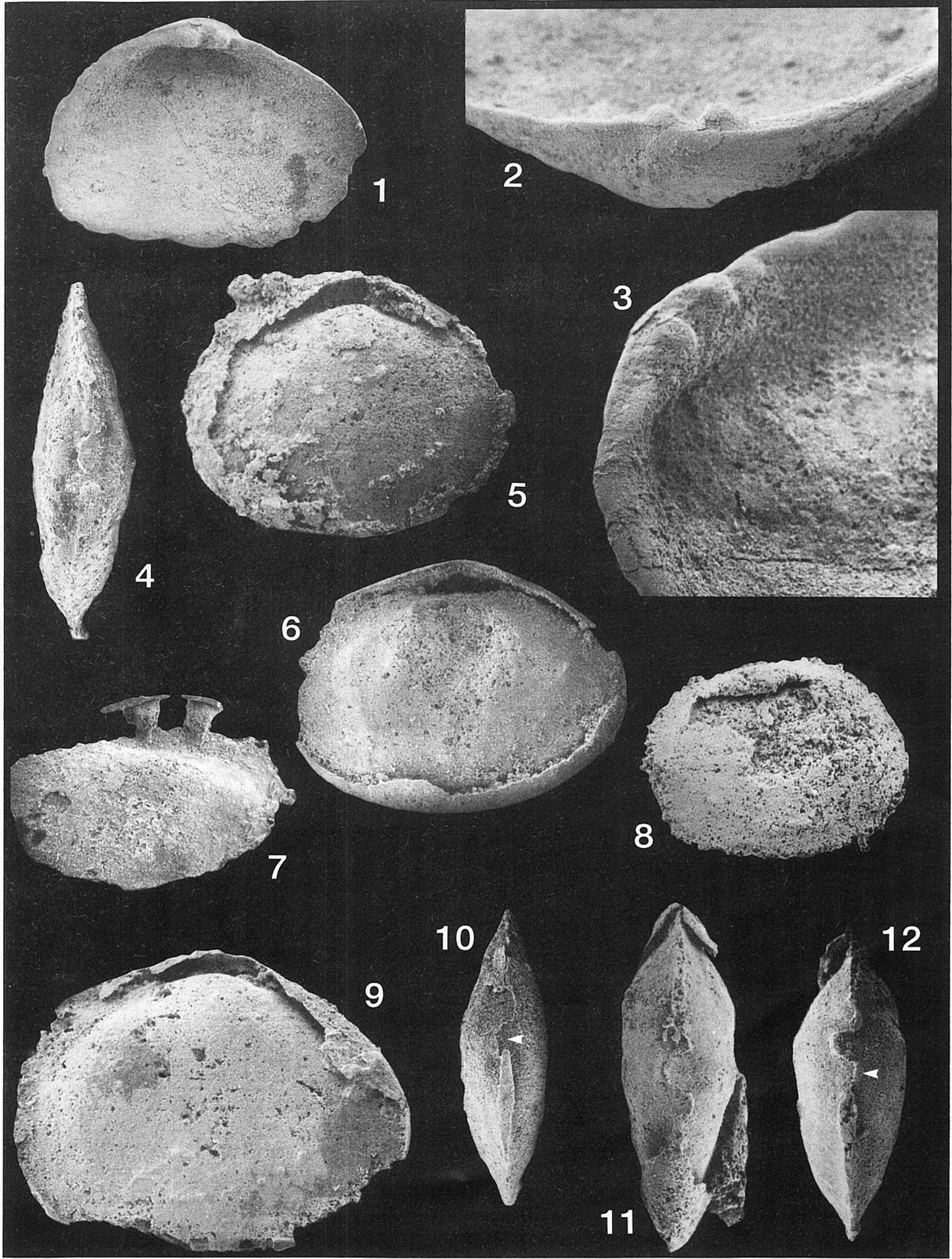

Revista Española de Paleontología, no extr. Homenaje al Prof. Gonzalo Vidal, 1998. 


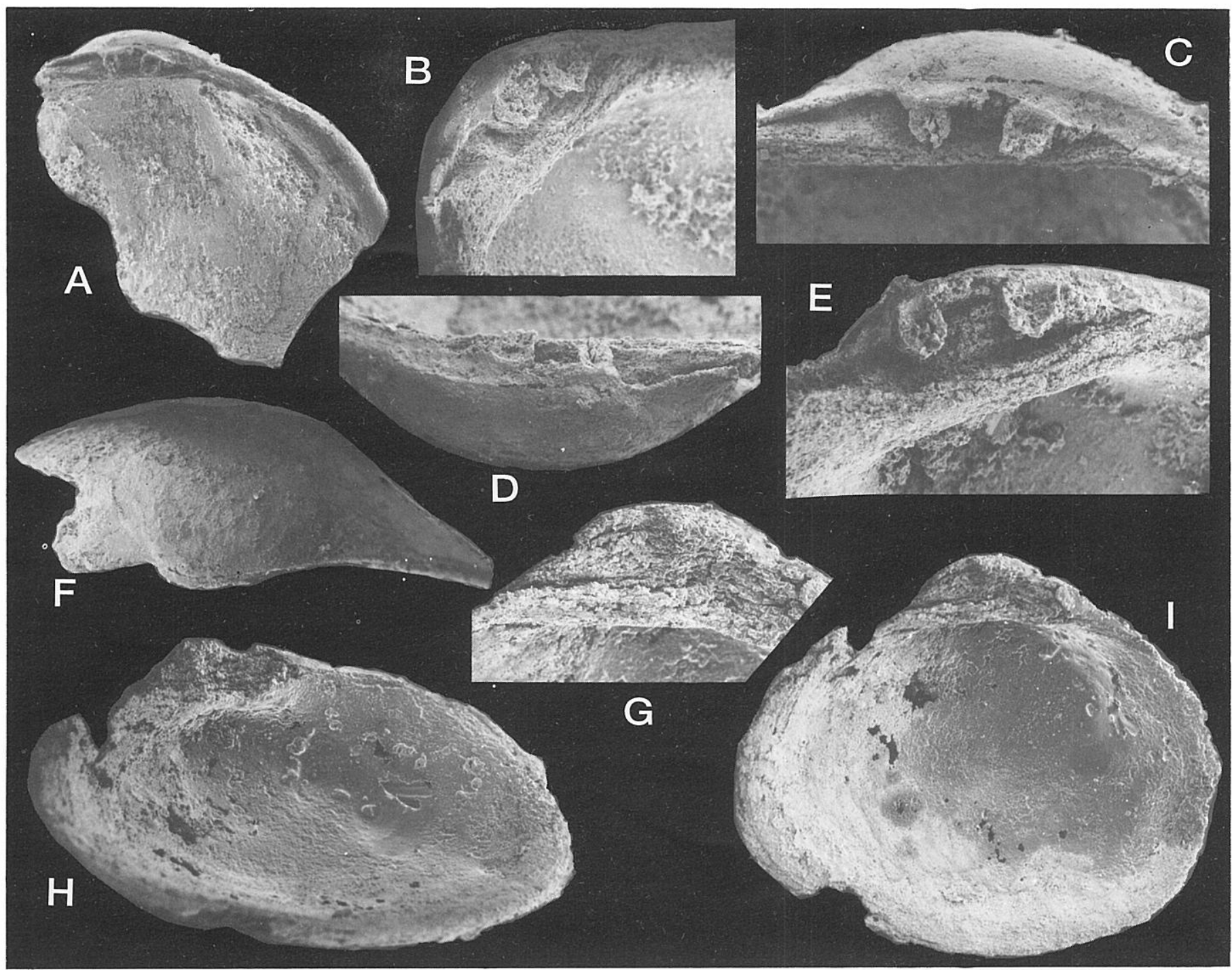

Figure 7. Arhouriella opheodontoides n. gen., n. sp. • A-E. Holotype, PIW 1997IV20, incomplete right valve. • A. View of internal side. $(\mathrm{x} 40.) \cdot \mathrm{B}$. Oblique anterior view of hinge area showing overhanging hinge teeth, deep ligament groove anterior to anterior hinge tooth and steeply sloping anterior part of hinge plate. $(x 100$.) $\bullet$ C. Lateral view of hinge area with hinge teeth undercut by hinge plate with growth lines. (x100.) Note anterior ligament fosette that projects posteriorly into a shallow groove beneath the hinge teeth and lancet-shaped ligament area posterodorsal to posterior hinge tooth. • D. Slightly oblique dorsal view of hinge area. (x 100.) • E Slightly oblique anterior view of hinge area showing overhanging hinge teeth, deep ligament groove anterior to anterior hinge tooth and swollen anterior part of hinge plate. (x110.) • F-I. Paratype, PIW 1997IV8, left valve. • F. Dorsal view showing convexity and faint growth lines in the umbonal area. $\bullet$ G. Lateral view of hinge area showing imperfectly preserved ligament groove. (x80.) • H. Oblique posteroventral view showing anterior adductor muscle scar. (x55.) • I. Lateral view. (x45.)

germanica differs from the other species of the genus in the rather conspicuous elongation of the valves and the umbones that are short distance anterior to the center of the dorsal margin. It should be noted that the size of the holotype (Elicki, 1994: fig. 4,13) is indicated as being 3.0 $\mathrm{mm}$, which would be the largest ever published specimen of an Early Cambrian pelecypod.

Elicki (1994) also figures a (normal sized) specimen identified as Pojetaia runnegari. The specimen is not described in the text, but comes from the same locality and stratum as $P$. germanica. It shows a remarkable similarity with the Australian material and has the relatively strongly projecting umbones, but its auricle is apparently less well defined and not completely preserved in the figured specimen. Additional material needs to be examined to evaluate the precise identity.

Pojetaia ostseensis Hinz-Schallreuter, 1995 was described from the Middle Cambrian (Triplagnostus gibbus Zone) Exsulans Limestone of Bornholm. Although the material is relatively large (length of the valves about 1.3 to $1.7 \mathrm{~mm}$ ), the dentition with three distinct teeth and the comparatively elongate shape (length-to-width ratio 1.50 to 1.54 ) is relatively characteristic. The auricle angle is large (around $135^{\circ}$ ).

Table I gives an overview of the most important characters seen in the species of Pojetaia. 


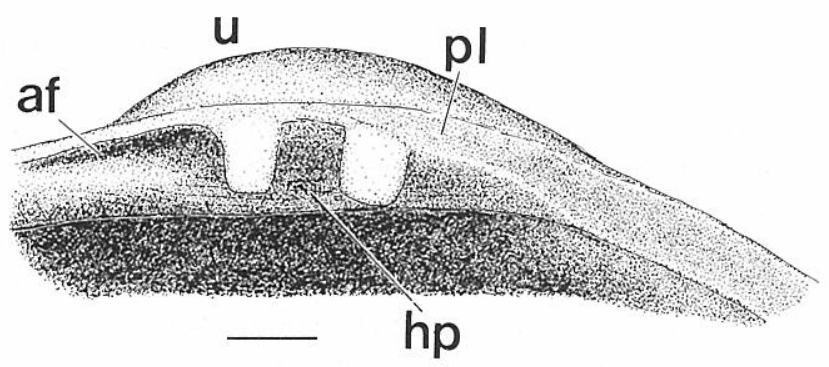

Figure 8. Arhouriella opheodontoides n. gen., n. sp. Reconstruction of hinge area. Scale bar equals 100 $\mu \mathrm{m}$. Abbreviations: $\mathrm{af}=$ anterior fossette, $\mathrm{hp}=$ hinge plate, $\mathrm{pl}=$ posterior ligament area, $\mathrm{u}=\mathrm{umbo}$.

\section{SUBCLASS AND ORDER UNDETERMINATE}

Family Arhouriellidae n. fam.

Diagnosis: Shell equivalved, equilateral. Valves veneriform and suboval to subelliptical. Umbones prosogyrate. Dorsal margins of valves strengthened. Ligament amphidetic. Right valve with dentition consisting of two teeth that overhang the hinge plate.

Arhouriella n. gen.

Type species: Arhouriella opheodontoides n. gen., n. sp.

Diagnosis: Diagnosis of the family.

Derivatio nominis: Named after Jbel Arhouri.

Discussion: See discussion under Arhouriella opheodontoides.

Arhouriella opheodontoides n. gen., n. sp. Figs. 7, 8

Holotype: PIW 1997IV20, incomplete right valve (Fig. 7AE).

Paratype: PIW 1997IV8, right valve.

Locus typicus: Jbel Arhouri section, east-central Anti-Atlas.

Stratum typicum: Sample horizon JAR-0.56, Jbel Wawrmast Formation, Brèche à Micmacca Member; Cephalopyge notabilis Zone, early Middle Cambrian.

Derivatio nominis: From the classical Greek ó $\phi \iota \sigma,-\epsilon \omega \sigma$ (snake), and $\delta \delta \omega \nu$, -ó $\nu T O \sigma$ (tooth); an allusion to the hingeteeth that project like in the mouth of a snake.

Diagnosis: Diagnosis of the genus (because of monotypy).

\section{Description}

The description is based on two right valves, one of which is incomplete, the other only bears a poorly preserved hinge area. The identification as right and left valves is based on (1) the oval shape of the valves with a better rounded posterior margin as in comparable Early Paleozoic forms, and (2) the presence of a faint imprint interpreted as posterior adductor muscle scar.

Shell apparently equivalved and roughly equilateral. Valves suboval to subelliptical, without distinct auricle. Umbo apparently slightly prosogyrate, projects faintly beyond the hinge. Exterior of valves with faint growth lines.

Interior of valves smooth, except for single, large adductor muscle scar in posterior position (Fig. 7H). Faint pallial commences at adductor muscle scar.

Best evidence for the morphology of the hinge and the ligament comes from the partially preserved, silicified right valve. The fragment includes the posterodorsal portion of the valve with the hinge and part of the ligament area so that the most important characters are visible.

Internally is a well developed hinge plate the surface of which is covered with fine growth lines. Apparently, this hinge plate was partly covered with the ligament. The hinge plate is slightly concave in ventral view and forms a platform that undercuts the dentition and is defined posterodorsally by a narrow platform which is interpreted as a ligament area. In its anterior part, the hinge plate is strongly convex in transverse section and slopes rapidly towards the valve floor so that it consists of a narrow ridge bordered dorsally by a groove (Fig. 7B, E). In contrast, its sector beneath the hinge teeth is wider and nearly plain.

Two sites of apparent ligament attachment are recognizable. One is a fossette anterior to the umbo that represents a ligament groove which continues posteriorly and ends close to the anterior of the hinge teeth. Another ligament area is located posterior and dorsal to the posterior hinge tooth and has a broad lancet shape (Fig. 7C). Slightly anterior to the beak the ligament was partly covered dorsally by a transversely narrow band of the dorsal valve margin (Fig. 7B, D), whereas no dorsal cover is present at the ligament area posterior to the beak.

The dentition consists of two teeth, which originate close to the dorsal margin of the valve, although a hinge plate is developed. These teeth project ventrally and are somewhat undercut (Fig. 7E). The anterior tooth originates with a comparatively massive base directly at the dorsal margin, whereas the posterior tooth is in a slightly more ventral position because of the dorsally adjacent ligament area.

\section{Discussion}

This arrangement of teeth and ligament area is totally new and unexpected for Cambrian pelecypods. It suggests the presence of an amphidetic and partly internal ligament that obviously was placed directly between the valve margins and could extend dorsally only at its anterior and posteriormost parts. Even beyond, the structure of the hinge plate that undercuts the teeth suggests that at least the anterodorsal part beneath the anterior tooth, but probably the entire middle sector of the hinge plate, was covered by ligament in an earlier ontogenetic stage. Thus, it may be concluded that the valves of Arhouriella were attached mainly by a long ligament in juveniles. The hinge teeth apparently 
developed in a later stage and then projected over the now infunctional middle part of the hinge plate. This serves for the remarkable absence of clearly developed sockets.

This condition strongly differs from the strictly opisthodetic ligament in Fordilla and Pojetaia. The dentition in Arhouriella also suggests an advanced rather than a primitive state. These conditions are unlike the primordial taxodont condition as in Fordilla and Pojetaia.

\section{THE ORIGIN OF THE PELECYPODS}

The few findings of Early and Middle Cambrian pelecypods and their mostly imperfect preservation and limited amount of characters do not permit a well-based reconstruction of their early phylogeny and origin. Most of the recognizable characters seen in Pojetaia and Fordilla are more-or-less directly related to the small sizes of these animals, such as the few hinge teeth, the straight ligament, and the dispersed pallial muscle insertions (Runnegar and Bentley, 1983). It is remarkable, however, that pelecypods remain relatively poorly diverse in the second burst of the Cambrian explosion, when a great number of different fossil groups attained large numbers of species and individuals.

Two facts should be emphasized that shed some light on the aspects of pelecypod phylogeny and origin. Reconstructions of the earliest pelecypods with originally exogastric coiling (Peel, 1991a) appear sound. This would suggest that pelecypods did not develop from helcionelloid via rostroconch ancestors as commonly assumed (Runnegar and Pojeta, 1974; Pojeta, 1980; Runnegar and Bentley, 1983), because rostroconchs are now widely accepted as endogastric and derived from the endogastric Helcionelloida (Peel, 1991a, b; Geyer, 1994). This, in turn, does not support arguments for a possible epifaunal origin of pelecypods although a reconstruction of earliest pelecypods as epifaunal suspension feeders (Tevesz and McCall, 1976) may be hypothesized. However, it remains a puzzling fact that the apparent multiple paired pedal muscle scars seen in Fordilla and Pojetaia leave little space to accommodate a gill apparatus of appropriate size for suspension feeding although Runnegar and Bentley (1983) argued that Pojetaia and Fordilla are small enough to operate as suspension feeders without specialized organs like juvenile specimens of the extant Nucula. Although the specimens examined during this study come from shell hash layers, most of them are preserved bivalved. This indicates that they lived infaunal and that the sampled horizon represents their original habitat.

Early pelecypods apparently do not show a constant pattern of distinct muscle scars. The number and size of muscle scars seen in Pojetaia sarhroensis vacillates. This suggests that the muscle attachment is derived from a thin band of attached tissue concentric to the apex. Such a band is split into a rough track of muscle imprints rather than it depicts discrete pattern of scars. It is hence doubtful whether all the muscle scars can be directly compared among species or even genera although groups representing subsequent anterior pedal retractor muscle scars or anterior adductor muscle scars can be identified (compare Pojeta and Runnegar, 1985).

Fordilla and Pojetaia both share an opisthodetic ligament and simple dentition, which is interpreted as the primordial condition in the pelecypods that gave rise to the later nuculides and mytiloides (Jell, 1980; Runnegar and Bentley, 1983; Pojeta and Runnegar, 1985). In this light, the arrangement of well developed teeth and an amphidetic and partly internal ligament in Arhouriella $\mathrm{n}$. gen. is totally unexpected. This form cannot be accommodated under the Nuculoida and even suggests the presence of an second subclass of pelecypods in the early Middle Cambrian. However, the morphological details visible on the studied material are insufficient to permit further conclusions. In addition, it seems inappropriate in the present state of knowledge on Cambrian pelecypods to base hypotheses on systematic affinities and early phylogeny on the Cambrian pelecypod record.

\section{ACKNOWLEDGEMENTS}

The authors are indebted to Sha Jingeng, who made available some of the Chinese literature and translated parts of the Chinese descriptions. Thanks are also due to Shu Degan for Chinese literature. Wolfram Heldmaier kindly provided information on the Jbel Arhouri section and thin sections of the sample horizon. In addition, this study benefitted from discussions with F. T. Fürsich and Sha Jingeng on Arhouriella and from a helpful review by P. Jell (Brisbane). The SEM micrographs were taken in the Biozentrum of the Würzburg University (ZEISS DSM 962) and in the Fachbereich für Geowissenschaften, Universität Bremen (CamScan 44).

\section{REFERENCES}

Barrande, J. 1881. Système Silurien du Centre de la Bohême. VI. Bellmann, Paris. 226 pp.

Berg-Madsen, V. 1987. Tuarangia from Bornholm (Denmark) and similarities in Baltoscandian and Australasian late Middle Cambrian faunas. Alcheringa, 11, 245-259.

Chen Yi-yuan and Wang Zi-qiang. 1985. [A bivalve from the Lower Cambrian Xinji Formation in western Henan Province.] Earth Science, Journal of the Wuhan College of Geology, 10, 27-29. [In Chinese with English abstract.]

Dall, W. H. 1889. On the hinge of pelecypods and its development, with an attempt toward a better subdivision of the group. American Journal of Science, 38, 445-462.

Elicki, O. 1994. Lower Cambrian carbonates from eastern Germany: Palaeontology, stratigraphy and palaeogeography. Neues Jahrbuch für Geologie und Paläontologie, Abhandlungen, 191, 69-93. 
Fletcher, T. P. 1972. Geology and Lower to Middle Cambrian trilobite faunas of southwest Avalon, Newfoundland. Part Two. Ph. D. thesis, University of Cambridge. 295 pp. [Unpublished.]

Geyer, G. 1989. Late Precambrian to early Middle Cambrian lithostratigraphy of southern Morocco. Beringeria, 1, 115-143.

Geyer, G. 1990a. Die marokkanischen Ellipsocephalidae (Trilobita: Redlichiida). Beringeria, 3, 1-363.

Geyer, G. 1990b. Revised Lower to lower Middle Cambrian biostratigraphy of Morocco. Newsletters on Stratigraphy, 22, 53-70.

Geyer, G. 1990c. Proposal of formal lithostratigraphical units for the Terminal Proterozoic to early Middle Cambrian of southern Morocco. Newsletters on Stratigraphy, 22, 87-109.

Geyer, G. 1990d. Correlation along the Lower/Middle Cambrian boundary - a puzzling story with an elusory end? In: Tretij mezhdunarodnyj simpozium po kembrijskoj sisteme. [Third International Symposium of the Cambrian System.] 1-9 avgusta 1990 g., SSSR, Novosibirsk. Tezisy dokladov. (Eds. L. N. Repina i A. Yu. Zhuravlev), 100-102.

Geyer, G. 1993. The giant Cambrian trilobites of Morocco. Beringeria, 8, 71-107.

Geyer, G. 1994. Middle Cambrian mollusks from Idaho and early conchiferan evolution. In: Studies in Stratigraphy and Paleontology in Honor of Donald W. Fisher. (Ed. E. Landing). New York State Museum Bulletin, 481, 69-86.

Geyer, G. 1998. Intercontinental, trilobite-based correlation of the Moroccan early Middle Cambrian. Canadian Journal of Earth Sciences, 35 (4), 374-401.

Geyer, G. and Landing, E. 1995. The Cambrian of the Moroccan Atlas region. In: Morocco '95. The LowerMiddle Cambrian standard of western Gondwana. Introduction, Field Guide, Abstracts, and Proceedings of the First Conference of the Lower Cambrian Stage Subdivision Working Group and I.G.C.P. Project 366 Ecological Aspects of the Cambrian Radiation. (Eds. G. Geyer and E. Landing). Beringeria, Special Issue 2, 7-46.

Geyer, G. and Mergl, M. 1995. Mediterranean representatives of the obolellid Trematobolus (Brachiopoda) and a review of the genus. Paläontologische Zeitschrift, 69 , 179-209.

Geyer, G. and Palmer, A. R. 1995. Neltneriidae and Holmiidae (Trilobita) from Morocco and the problem of Early Cambrian intercontinental correlation. Journal of Paleontology, 69, 459-474.

Geyer, G., Landing, E. and Heldmaier, W. 1995. Faunas and depositional environments of the Cambrian of the Moroccan Atlas region. In: Morocco '95. The LowerMiddle Cambrian standard of western Gondwana. Introduction, Field Guide, Abstracts, and Proceedings of the First Conference of the Lower Cambrian Stage Subdivision Working Group and I.G.C.P. Project 366 Ecological Aspects of the Cambrian Radiation. (Eds. G. Geyer and E. Landing). Beringeria, Special Issue 2, 47 119.

Goldfuss, G. A. 1820. Handbuch der Zoologie. 2 volumes. J. L. Schrag, Nürnberg. 473 pp.
Havlícek and Kříż, J. 1978. Middle Cambrian Lamellodonta simplex Vogel: "Bivalve" turned brachiopod Trematobolus simplex (Vogel). Journal of Paleontology, 52, 972-975.

He Ting-gui and Pei Fang. 1985. [The discovery of bivalves from the Lower Cambrian Xinji Formation in Fangcheng County, Henan Province.] Journal of Chengdu College of Geology, 1985 (1), 61-66. [In Chinese with English abstract.]

Hinz-Schallreuter, I. 1995. Muscheln (Pelecypoda) aus dem Mittelkambrium von Bornholm. Geschiebekunde aktuell, 11 (3), 71-84.

Hupé, P. 1959. Nouvelle contribution à l'étude du Cambrien marocain. Thèse, Université de Paris. 447 pp. [Unpublished.]

Jell, P. A. 1980. Earliest known pelecypod on Earth - A new Early Cambrian genus from South Australia. Alcheringa, 4, 233-239.

Korobkov, L. A. 1954. Spravochnik i metodicheskoe rukovodstvo po tretichnym mollyuskam platinchatozhaberne. $\mathrm{X}$. Trudy gosudarstvennogo issledovatel'skogo instituta nefti, 11, 1-24. [In Russian.]

Krasilova, I. N. 1977. Fordillidy (Bivalvia) iz nizhnego paleozoya Sibirskoj platformy. [Fordillids (Bivalvia) from the lower Paleozoic of the Siberian platform.] Paleontologicheskij Zhurnal, 1977 (2), 42-48. [In Russian.]

Landing, E. 1992. Lower Cambrian of southeastern Newfoundland. Epeirogeny and Lazarus faunas, lithofacies-biofacies linkages, and the myth of global chronology. In: Origin and Early Evolution of the Metazoa. (Eds. J. H. Lipps and P. W. Signor). Plenum Press, New York, 283-309.

Li Yuwen and Zhou Benhe. 1986. [Discovery of old microbivalves in China and its significance.] Dizhi Kexue [Scientia Geologica Sinica], 1986 (1), 38-45. [In Chinese with English abstract.]

MacKinnon, D. I. 1982. Tuarangia paparua n. gen. and n. sp. A late Middle Cambrian pelecypod from New Zealand. Journal of Paleontology, 56, 589-598.

McAlester, A. L. 1969. Type species of Paleozoic nuculoid bivalve genera. Geological Society of America Memoir, 105, 1-143.

Peel, J. S. 1991a. The Classes Tergomya and Helcionelloida, and early molluscan evolution. Gronlands geologiske Unders $\phi$ gelse Bulletin, 161, 11-65.

Peel, J. S. 1991b. Functional morphology of the Class Helcionelloida nov., and the early evolution of the Mollusca. In: The early evolution of Metazoa and the significance of problematic taxa. Proceedings of an International Symposium held at the University of Camerino, 27-31 March 1989. (Eds. A. M. Simonetta and S. Conway Morris). Cambridge University Press, Cambridge, New York, Melbourne, Port Chester, Sydney, 157-177.

Pojeta, J., Jr. 1971. Review of Ordovician pelecypods. United States Geological Survey Professional Paper, 695, 1-46.

Pojeta, J., Jr. 1980. Molluscan Phylogeny. Tulane Studies in Geology and Paleontology, 16, 55-80. 
Pojeta, J., Jr. and Runnegar, B. 1985. The Early Evolution of Diasome Molluscs. In: The Mollusca, Volume 10. Evolution. (Eds. E. R. Trueman and M. R. Clarke). Academic Press, Orlando, San Diego, New York, 295336.

Robison, R. A., Rozova, A. V., Rowell, A. J. and Fletcher, T. P. 1977. Cambrian boundaries and divisions. Lethaia, 10, 257-262.

Runnegar, B. 1983. Molluscan phylogeny revisited. Association of Australasian Palaeontologists Memoir, 1, 121-144.

Runnegar, B. and Bentley, C. 1983. Anatomy, ecology, and affinities of the Australian Early Cambrian bivalve Pojetaia runnegari Jell. Journal of Paleontology, 57, 7392.

Runnegar, B. and Pojeta, J., Jr. 1974. Molluscan phylogeny: the paleontological viewpoint. Science, 186 (4161), 311317.

Runnegar, B. and Pojeta, J., Jr. 1985. Origin and diversification of the Mollusca. In: The Mollusca. Volume 10, Evolution. (Eds. E. R. Trueman and M. R. Clarke). Academic Press, Orlando, San Diego, New York, 1-57.

Shu Degan. 1986. [Notes on the oldest fossil bivalves from the Niutitang Formation of Fuquan, Guizhou.] Acta Palaeontologica Sinica, 25, 219-222. [In Chinese with English abstract.]

Tevesz, M. J. S. and McCall, P. L. 1976. Primitive life habits and adaptive significance of the pelecypod form. Paleobiology, 2, 183-190.

Vogel, K. 1962. Muscheln mit Schloßzähnen aus dem spanischen Kambrium und ihre Bedeutung für die Evolution der Lamellibranchiaten. Akademie der Wissenschaften und der Literatur in Mainz, mathematischnaturwissenschaftliche Klasse, Abhandlungen, 1962 (4), 193-244.

Vogel, K. 1975. Forschungsbericht über Muscheln. Paläontologische Zeitschrift, 49, 477-492.

Yermak, V. V. 1986. Rannekembrijskie fordillidy (Bivalvia) severa Sibirskoj platformy. [Early Cambrian fordillids (Bivalvia) from the northern Siberian Platform.] In: Biostratigrafija i paleontologija kembrija Severnoj Azii. [Biostratigraphy and palaeontology of the Cambrian of northern Asia.] (Ed. I. T. Zhuravleva). Trudy Instituta geologii i geofiziki, Sibirskoe otdelenie, Akademija nauk SSSR, 669, 183-188. [In Russian.]

Yu Wen. 1985. [Yangtzedonta - A problematic Bivalvia from the Meishucunian Stage, China.] Acta Micropalaeontologica Sinica, 2 (4), 401-408. [In Chinese with English summary.]

Zhang Renjie. 1980. [The earliest bivalve fauna; bivalves from the Lower Cambrian Tianheban Formation, Xianfen, Hubei.] Yichang Dizhi Kuangchan Yanjiuso Sokan [Bulletin of the Yichang Institute of Geology and Mineral Resources, Chinese Academy of Geological Sciences], 1 (1), 1-17. [In Chinese with English abstract.] 